\title{
The Effective Ecological Factors and Vegetation at Koh Chang Island, Trat Province, Thailand
}

\author{
Nathsuda Pumijumnong, Paramate Payomrat \\ Faculty of Environment and Resource Studies, Mahidol University, Nakhon Pathom, Thailand \\ Email: nathsuda@gmail.com, paramate.ohm@gmail.com
}

Received October $3^{\text {rd }}, 2012$; revised November $7^{\text {th }}, 2012$; accepted November $20^{\text {th }}, 2012$

\begin{abstract}
This study aims to characterize the tropical rain forest present in the Chang Island, Trat Province, Thailand, and to analyze the environmental factors to determine its composition and structure. Thirty one plots were sampled, plant cover was measured in $20 \times 40 \mathrm{~m}^{2}$ plots, and the importance value index was calculated. A total of 78 species belonging to 32 families were identified.Twenty soil samples were analyzed, and cluster analysis was employed to classify the vegetation communities. Floristic and environmental data were evaluated and ordered using canonical correspondence analysis. The results showed that the vegetation communities could be divided into 4 types and were significantly $(p<0.05)$ controlled by a secondary distribution according to elevation and the topographic wetness index (TWI). Mixed plant communities were more likely to distribute in regions with moderate to low levels of TWI, which were divided by levels of elevation into lowland multi-aged stands (Type 1) or a Calophyllum thorelii Pierre community (Type 2). The Dipterocarpus (Hopea pierrei Heim) community (Type 3) was more likely to occur in regions with moderate to high levels of TWI, but the result from cluster analysis showed that some of the plot samples from the Dipterocarpus community were separated by characteristic importance value index (IVI) values. There was also evidence that the area was impacted by an old disturbance created by a rubber plantation. This impact was referred to as a secondary succession community (Type $4)$.
\end{abstract}

Keywords: Chang Island; Vegetation Community; Canonical Correspondence Analysis; Ecological Factors

\section{Introduction}

Chang Island is one of only a few islands where a tropical rain forest is distributed over $70 \%$ of the inland area, which has been preserved in its present form (Environmental Research Institute, 2007). The island covers an area of $212.947 \mathrm{sq} \mathrm{km}$ and is a major island of the Mu Koh Chang National park in the Gulf of Thailand, which became Thailand's 45th National Park in 1982. During the Pleistocene epoch (Tougard, 2001; Esselstyn et al., 2009), large sea level fluctuations caused the sea level to fall by $50-150 \mathrm{~m}$, creating land bridge connections. After this period, the sea level rose and the low-lying regions were covered with water forming many islands separated from the mainland. Various fossils have confirmed these events during this period (Bird et al., 2005). The research of Chamchumroon and Puff provides evidence to support this theory. It is remarkable that although a large proportion of rubiaceous taxa show disjunction between Koh Chang and peninsular Thailand, $20 \%$ of all rubiaceae taxa recorded from Koh Chang have been found to be distributed in peninsular Thailand (Chamchumroon et al., 2003). This indicates that biological species found on the mainland may also be found on the Chang islands with a greater diversity. The tropical rain forest of Chang island has important roles in storing bioelements and water for local communities and acts as a carbon bank that impacts a large global area. Since 1902, the records of Schmidt (1900) have shown that all of the hills of Koh Chang are entirely covered with the densest jungle. In addition, the Siamese and Chinese populations scattered along the coasts where the river debouches have had little influence on the forest cover of the hills. Over the past century, tropical rain forest areas around the world and in Thailand now face loss due to human activities (Royal Forest Department, 1997, 2005). Chang Island is also facing the same problem as other forest resources and is in danger of losing forest cover by people focused on acquiring forest land for their settlements, farms, and plantations. Recently, land use change caused by tourism had led to construction on the island, including business buildings, luxury accommodations, roads, and harbors. This type of land use changes the ecological system of Chang Island. Although the Mu Ko Chang National Park was established at the end of 1982, negative human impact on the vegetation had already occurred in the more accessible coastal areas because the settled area of the old communities before the establishment of the National Park were not included in the preservation. Therefore, some species have become extinct, such as Ixoradoli chophylla, Lasianthuso ligoneuron and L. schmidtii, which according to the reports of Schmidt and Kerr (Chamchumroon et al., 2003; Schmidt, 1900), come from the Klong Nonsi area, a populated area near the Koh Chang District Office that has no traces of natural vegetation left. None of these species have ever been identified anywhere else in the Island. The effect of climate change is another problem because the area, size, and isolation of Chang Island make it less resilient to such change.

This study aimed to classify the vegetation communities on Chang Island and determine environmental factors that influence their composition and structure. Knowledge of these relationships may be critically important for planning appropriate adaptations to climate changes and disturbances due to human activities. 


\section{Materials and Methods}

\section{Study Area}

The study area is located at Chang Island, Trat Province, in the southeastern region of Thailand close to the border with Cambodia. It is located at $132^{\circ} 51^{\prime} 57^{\prime \prime} \mathrm{N}-134^{\circ} 51^{\prime} 57^{\prime \prime} \mathrm{N}$ and $20^{\circ} 10^{\prime}$ $46^{\prime \prime} \mathrm{E}-22^{\circ} 08^{\prime} 89 " \mathrm{E}$. The total area is approximately 212.947 square kilometers. Its length from north to south is 30 kilometers and the width is 14 kilometers. Chang Island is the largest island in Trat Province. It is close to the Cambodia border, approximately 300 kilometers southeast of Bangkok. Ninety percent of the total area is comprised of an extrusive and intrusive igneous rock mountain range interchanged with cliffs, steep hills, and cliffs reaching as high as $743 \mathrm{~m}$ above sea level (ASL), such as the Kao Yai Mountain. The plains along the east coast of the island are rich in sandy clay and the west coast is rich in a recent beach deposit (Tansuwan, 2007). Small rivers and streams on Chang Island are found in areas where the sea and the creeks meet, flowing through small mangrove forests around the island, with the exception of a fairly large forest located in a protected area on the south coast. The mountain slopes are covered by dense tropical rainforest forest. The principle tree species include Dipterocarpus alatus, D. turbinatus, Anisoptera costata, Hopea odorata, Irvingia malayana, Podocarpus neriifolius, Diospyros spp., Castanopsis spp., Croton spp., Oncosperma horrida, Caryotamitis., Daemonorops spp., Korthalsia grandis, Bauhinia bracteata, Freycinetia sumatrana, Platycerium coronarium, Amomum spp., Boesenbergia pandurata, and Kaempferia pulchra (Royal Forest Department, 1997, 2005). The climate conditions are influenced by northeast and southwest Asian monsoons; the former bring dry air to Thailand during November through April separated by short periods of cool (November-February) and hot (March-April) seasons, and the latter bring moisture from May through October and account for $90 \%$ of the annual rainfall. The mean annual rainfall is $4902 \mathrm{~mm}$ and total rain fall in some years surpasses 6000 $\mathrm{mm}$ (2000 AD, $2006 \mathrm{AD})$. In addition, the average maximum, minimum, and mean temperatures are $31.8^{\circ} \mathrm{C}, 23.6^{\circ} \mathrm{C}$, and $27.4^{\circ} \mathrm{C}$, respectively (Thai Meteorological Department, 2010).

\section{Field Sampling}

A quantitative survey of the vegetation was conducted along the entire topographic gradient of the protected area from North to South (Figure 1). A total of 31 plot samples were divided within the 4 survey lines. All samples from the plots were collected in year 2011. A temporary sample plot method was used in each sample plot. A quadrat of $20 \times 40 \mathrm{~m}^{2}$ was set and used to investigate all tree plants higher than $1.3 \mathrm{~m}$ with a diameter at breast height $(\mathrm{DBH}) \geq 4.5 \mathrm{~cm}$. One $4 \times 4 \mathrm{~m}^{2}$ quadrat was used to sample plants with a DBH less than $4.5 \mathrm{~cm}$ and higher than $1.3 \mathrm{~m}$, and one $1 \times 1 \mathrm{~m}^{2}$ quadrat was used to analyze seeding plants shorter than $1.3 \mathrm{~m}$ with a DBH less than $4.5 \mathrm{~cm}$. Elevation, slope, aspect, topographic wetness index (TWI) (Sørensen et al., 2005) were measured in every plots. Twenty soil samples were randomly collected from 31 plots and correlated with the aspect and altitude change. For each site, the soil depth interval to collect samples was $30 \mathrm{~cm}$ from the top to a depth of $1 \mathrm{~m}$ or until the base rock was reached. These soil samples were air dried and passed through a $2 \mathrm{~mm}$ sieve to remove coarse gravels, roots, and debris. The soil texture, bulk density, soil moisture, $\mathrm{pH}$ value, soil organic carbon, total nitrogen, avail- able phosphorus, and exchangeable potassium were subsequently analyzed in these samples (Office of Science for Land Development, 2005).

\section{Data Analysis}

A species list was created to further simply identification of species diversity. We also determined three values for each tree species in a given community, including the relative density, relative frequency, and relative dominance (dominance was defined as the mean basal area per tree times the number of trees of the species) (Curtis, 1959). The diversity within a community was calculated using the Shannon-Wiener index $(\mathrm{H})$ (Hill, 2007). Multivariate analyses were performed on the floristic data matrices, species, where all species whose importance value was less than 5\% were eliminated. Classification of plant communities was achieved using a two-way cluster analysis on the PC-ORD program (Finch, 2005; McCune, 2002). Thirty-one plots of plant communities were classified based on the important value of each species in each plot sampled. Ordination was performed within PC-ORD using canonical corresponded analysis (CCA) (McCune, 2002). CCA is a direct gradient analysis technique that relates community variation (composition and abundance) to environmental variation, thereby providing a determination of significant relationships between environmental variables and community distribution (terBraak, 1995). CCA axes were evaluated statistically using a Monte Carlo test. Four topographic variables and 11 soil properties were used in the CCA.

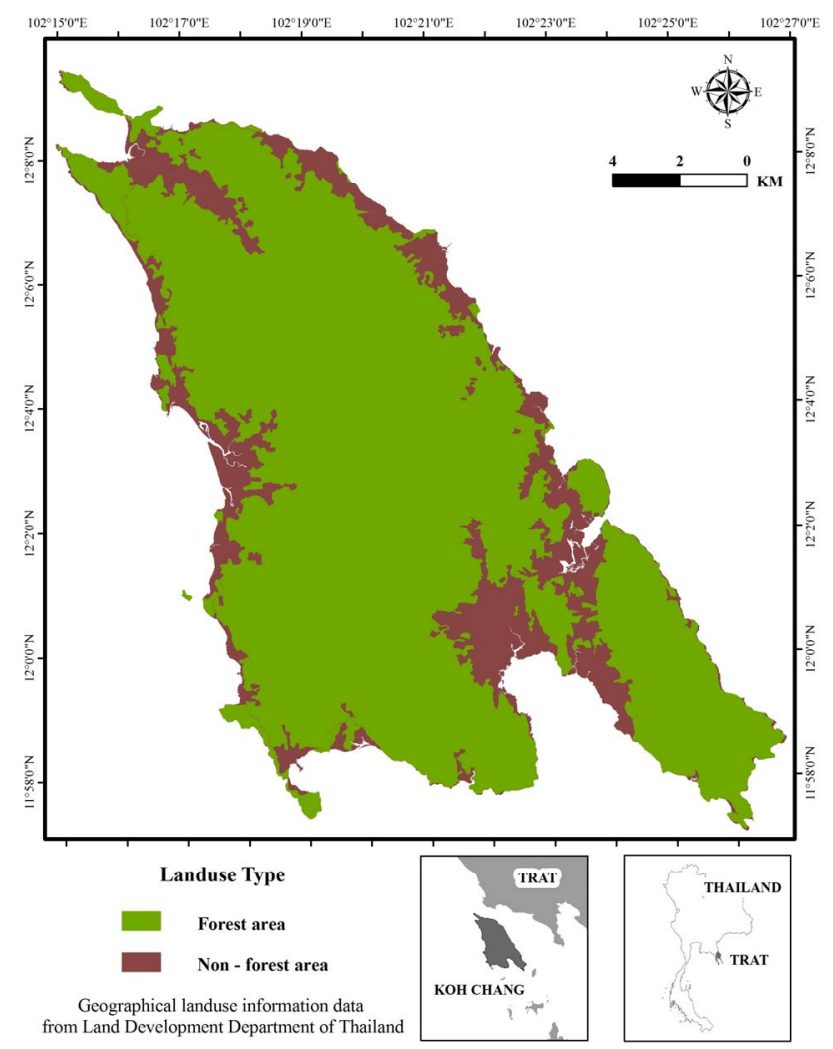

Figure 1.

Map of Chang Island obtained from a THEOS satellite image. The green indicates the study area. 


\section{Results and Discussion}

\section{Communities Classification}

The classification of sub-communities characterized in this study was different from the classification by the Department of Forestry (Santhisuk, 2006). At the country scale, the forest area of Chang Island was defined only as a tropical rainforest of one of the fourteen sub-communities of Evergreen Forests, based on three major factors. First, the climatic factor present in East Thailand is such that the mean annual rainfall is between 1760 and $3140 \mathrm{~mm}$. The number of days of rainfall is between 102 and 150 days, and the total rainfall in some years is more than $4000 \mathrm{~mm}$. When this is compared to the climate of Chang Island (see in 2.1), we can see that the rainfall is clearly higher than in other parts of Thailand. This is because most areas of Chang Island are not far from the sea, and steep mountains are able to capture clouds and cause them to ascend. Second, the elevation of tropical rainforest is limited to $900 \mathrm{~m}$ asl and the highest peak of Chang Island is $743 \mathrm{~m}$ asl. The last factor is the native natural dominant species, which have developed over a long period of time into climax stage communities. Cluster analyses play a substantial role in analyzing the complicated characteristics of an area that has little change in environmental gradient. This type of analysis of Chang Island was quite successful in identifying distinct vegetation communities in our study area from the IVI of each species. Four community types were created with $50.76 \%-76.66 \%$ of information remaining in at two-way cluster dendrogram (Figure 2), which indicated a good pattern in each community. Lowland multi-aged stands (Type 1) grouped from 6 samples and 60 species of stand trees in 27 families were recorded, and the IVI of each species was characterized. The species with IVI $>5 \%$ were Tetrameles nudiflora R. Br. (Tetramelaceae), Hopea pierrei Heim (Dipterocarpaceae), Madhuca pierrei Lam (Sapotaceae), Lithocarpus ceriferus A. Camus (Fagaceae), and Ficus callosa Willd (Moraceae). The Shannon-Wiener index for diversity was 5.19 and the absolute density was 1287 tree $\mathrm{ha}^{-2}$. The average tree height was $13.21 \pm 7.28 \mathrm{~m}$, and the average $\mathrm{DBH}$ was $47.03 \pm$ $39.36 \mathrm{~cm}$. This community is widely found at lowlands with moderate slopes and a relatively dry region in TWI. The Calophyllum thorelii Pierre community (Type 2) grouped from 7 samplings and 41 species of stand trees in 22 families was recorded, and the IVI of each spices was determined. The species with IVI $>5 \%$ were Calophyllum thorelii Pierre (Guttiferae), Mesuaferrea Linn(Guttiferae), Hopea pierrei Heim (Dipterocarpaceae), and Cleistocalyx operculatus Merr and Perry (Myrtaceae). Guttiferae is a family of tree species that grows from the coastal plains up to the mountain rain forest, and Myrtaceae is a major component of the understory layer. The Shannon-Wiener index for diversity was 4.43 and the absolute density was 2225 tree ha $^{-2}$. The average tree height was $12.31 \pm$ $10.51 \mathrm{~m}$, and the average DBH was $35.16 \pm 26.06 \mathrm{~cm}$. This community is widely found at medium to high elevations with moderate to steep slopes. The Hopea pierrei Heim community (Type 3) was classified first, with $78.66 \%$ of the information remaining while grouping due to the presence of the dominant Hopea pierrei Heim stand tree in each sampling (shown as the dark shade of matrix coding). The eight samples belonging to this community had 46 species of stand trees in 22 families characterized by Hopea pierrei Heim (family Dipterocapaceae), which is widely found in the forest area of Chang Island. However, the IVI ratio of each species of this community was occupied mainly by Hopea pierrei Heim IVI, rather than others species $(\mathrm{IVI}=114.44$ or $38.14 \%)$. Dipterocaps are inconspicu-

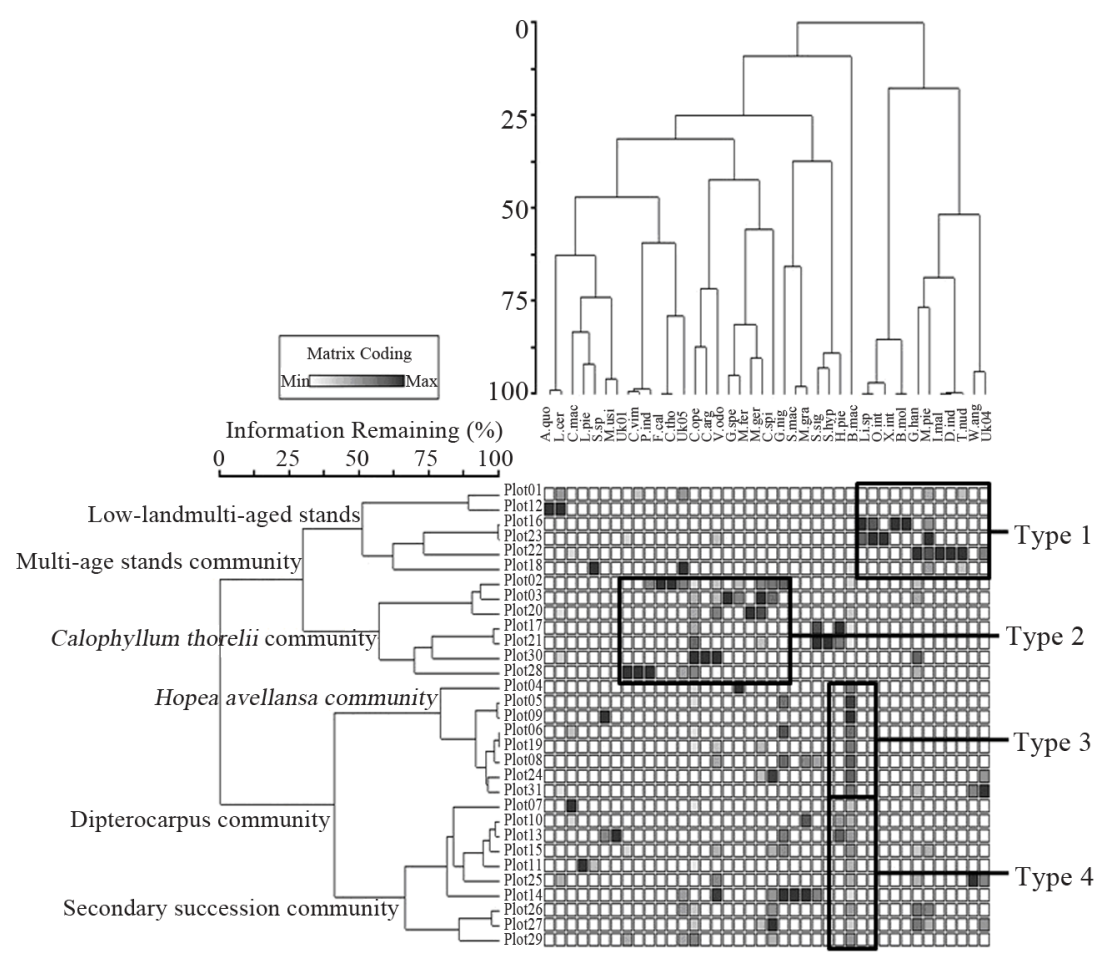

Figure 2.

Dendrogram derived from two-way cluster analysis of the vegetation data at the study area. Plots classification showing the indicator species for each division (see species code on Table 2). 
ous in the Neotropics and Afrotropics, but are the dominant trees in the Indomalayan region in most tropical lowland evergreen forests (Göltenboth et al., 2007). The Shannon-Wiener index for diversity was 3.96 (high species evenness and richness) and the absolute density was 1807 tree $\cdot \mathrm{ha}^{-2}$. The average tree height was $13.72 \pm 6.81 \mathrm{~m}$, and the average $\mathrm{DBH}$ was $40.97 \pm 49.13 \mathrm{~cm}$. This community is widely found at mid elevations with moderate to steep slopes and in relatively wet regions with a high TWI (Table 1). The secondary succession community(Type 4) emerged as a group from 10 samplings and 41 species of stand trees in 22 families characterized by Hopea pierrei Heim. Almost all of the species were similar to the Hopea pierrei Heim community (Type 3), but differed in the species abundance as defined by the IVI ratio. The Hopea pierrei Heim (Dipterocapaceae) abundance decreased from 38.14\% to $20.54 \%$ and the Shannon-Wiener index for diversity increased to 4.58 . The absolute density was 1782 tree ha $^{-2}$. The average tree height was $13.37 \pm 7.50 \mathrm{~m}$, and the average $\mathrm{DBH}$ was $40.76 \pm 34.65 \mathrm{~cm}$. This community is widely found at low to medium elevations with flat to moderate slopes and a moderate TWI. Some evidence pointed to a defined stage of secondary succession, including the spreading of death rubber trees in the sampling plots, interviews from local people, and the location of the plots near agriculture areas.

Although the classification of forest communities using clus-

Table 1.

Mean $( \pm$ ) standard deviation (SD) of environmental variables for the plots associated with each of the six community type.

\begin{tabular}{|c|c|c|c|c|}
\hline & \multicolumn{4}{|c|}{ Community types } \\
\hline & Type 1 & Type 2 & Type 3 & Type 4 \\
\hline Number of plots & 6 & 7 & 8 & 10 \\
\hline Number of species & 60 & 41 & 46 & 41 \\
\hline Shannon-wiener index & 5.19 & 4.43 & 3.69 & 4.48 \\
\hline Elevations (m sal.) & $210 \pm 57$ & $364 \pm 179$ & $320 \pm 72$ & $287 \pm 133$ \\
\hline Slope $\left({ }^{\circ}\right)$ & $14 \pm 9$ & $19 \pm 13$ & $20 \pm 14$ & $14 \pm 9$ \\
\hline $\begin{array}{l}\text { Topographic wetness index } \\
\text { (TWI) }\end{array}$ & $0.5 \pm 0.6$ & $1.29 \pm 1.2$ & $4.13 \pm 2.5$ & $1.70 \pm 2$ \\
\hline Soil depth $(\mathrm{cm})$ & $83 \pm 15$ & $68 \pm 29$ & $70 \pm 15$ & $60 \pm 19$ \\
\hline Organic matter (\%) & $4.1 \pm 0.6$ & $4.6 \pm 1.4$ & $3.9 \pm 1$ & $3.6 \pm 1.2$ \\
\hline $\mathrm{pH}$ & $4.4 \pm 0.5$ & $4.5 \pm 0.05$ & $4.3 \pm 0.2$ & $4.2 \pm 0.4$ \\
\hline Total nitrogen (\%) & $0.2 \pm 0.1$ & $0.2 \pm 0.1$ & $0.2 \pm 0.1$ & $2.1 \pm 0.1$ \\
\hline $\mathrm{CEC}(\mathrm{cmol} / \mathrm{kg})$ & $8.9 \pm 1.9$ & $8.3 \pm 1.5$ & $9.4 \pm 2.5$ & $10.1 \pm 3.2$ \\
\hline Available phosphorus (ppm) & $1.3 \pm 1.2$ & $1.8 \pm 0.9$ & $1.2 \pm 0.7$ & $1.9 \pm 0.7$ \\
\hline Exchangeable potassium (pmm) & $51 \pm 21.5$ & $46 \pm 16.7$ & $32 \pm 16.6$ & $32 \pm 9.3$ \\
\hline Exchangeable calcium (pmm) & $69 \pm 64.6$ & $34 \pm 12$ & $18.2 \pm 9.4$ & $16.7 \pm 9.0$ \\
\hline $\begin{array}{l}\text { Exchangeable magnesium } \\
\qquad(\mathrm{pmm})\end{array}$ & $42 \pm 42.6$ & $27 \pm 13$ & $14.8 \pm 9.6$ & $16.6 \pm 8.6$ \\
\hline Bulk Density $\left(\mathrm{g} / \mathrm{cm}^{3}\right)$ & $1.1 \pm 0.1$ & $1.0 \pm 0.1$ & $1.2 \pm 0.2$ & $1.2 \pm 0.2$ \\
\hline Sand (\%) & $50.0 \pm 11$ & $58.7 \pm 8$ & $52.2 \pm 13$ & $48.4 \pm 12$ \\
\hline Silt (\%) & $18.9 \pm 5$ & $14.0 \pm 3$ & $16.5 \pm 7$ & $18.7 \pm 6$ \\
\hline Clay (\%) & $31 \pm 8.3$ & $27 \pm 5.6$ & $31 \pm 7.4$ & $32.9 \pm 6$ \\
\hline
\end{tabular}

Table 2.

Recorded species and their Important Value Index (IVI) in each community type (con.).

\begin{tabular}{|c|c|c|c|c|c|}
\hline \multirow{2}{*}{ Species } & \multicolumn{5}{|c|}{ IVI } \\
\hline & Sp. code & Type 1 & Type 2 & Type 3 & Type 4 \\
\hline Aglaia cordata & A. cor & 4.36 & 1.03 & 0.61 & - \\
\hline Antidesma bunius & A. bun & - & 1.3 & 2.21 & - \\
\hline Antidesma laurifolium & A. lau & 0.75 & 1.2 & - & 1.98 \\
\hline Aquilaria crassna & A. cra & - & 2.54 & - & - \\
\hline Archidendron quocense & A. quo & 7.11 & 1.16 & - & 7.09 \\
\hline Artocarpus lanceifolius & A. lan & 0.76 & - & - & - \\
\hline Azadirachta var. siamensis & A. sia & 0.85 & - & 1.41 & - \\
\hline Baccaurea ramiflora & B. ram & 0.93 & 2.14 & - & - \\
\hline Barringtonia macrocarpa & B. mac & 10.63 & - & - & 1.96 \\
\hline Barringtonia racemosa & B. rac & 2.26 & - & 0.61 & - \\
\hline Bouea var. microphylla & B. mic & 2.3 & & 3.51 & 3.28 \\
\hline Bridelia affinis & B. aff & 0.7 & 1.1 & 2.66 & 2.9 \\
\hline Brucea javanica & B. jav & 0.7 & - & - & - \\
\hline Brucea mollis & B. $\mathrm{mol}$ & 4.18 & - & - & - \\
\hline Calophyllum thorelii & C. tho & 2.94 & 54.38 & 19.56 & 20.17 \\
\hline Carallia brachiata & C. bra & 4.02 & - & 1.38 & 0.76 \\
\hline Carpinus londoniana & C. lon & 8.35 & 8.23 & 5.72 & 10.41 \\
\hline Caryota bacsonesis & C. bac & - & - & 0.62 & - \\
\hline Chaetocarpus castanocarpus & C. cas & 3.45 & 1.09 & 0.87 & 2.97 \\
\hline Chisocheton siamensis & C.sia & 8.2 & 2.23 & 2.04 & 4.87 \\
\hline Cinnamomum bejolghota & C.bej & - & 0.97 & - & - \\
\hline Cleidion spiciflorum & C. spi & 9.64 & 8.84 & 14.57 & 12.46 \\
\hline Cleistocalyx operculatus & C. ope & 6.32 & 15.78 & 13.55 & 17.34 \\
\hline Cratoxylum maingayi & C. mai & 0.8 & 1.86 & - & - \\
\hline Croton argyratus & C. arg & 1.13 & 4 & 2.02 & 1.1 \\
\hline Dacrydium elatum & D. ela & - & 3.13 & - & - \\
\hline Diospyros decandra & D. dec & 0.77 & - & 0.66 & 2.58 \\
\hline Dipterocarpus sp. & D. $s p$ & 3.32 & 2.66 & 5.98 & 10.43 \\
\hline Dipterocarpus sp. 2 & D. sp2 & 2.61 & - & - & - \\
\hline Dipterocarpus turbinatus & D. tur & 0.74 & - & 1.69 & - \\
\hline Elaeocarpus robusus & E. rob & 0.79 & - & - & - \\
\hline Eurycoma longifolia & E. lon & 2.12 & 6.4 & 1.45 & 5.21 \\
\hline Fagraea fragrans & F. fra & - & 1.49 & - & - \\
\hline Ficus callosa & F.cal & 15.86 & 12.09 & 9.51 & 13.1 \\
\hline Firmiana colorata & F. col & 0.7 & - & - & - \\
\hline Garcinia hanburyi & G. han & 8.1 & 12.95 & 6.11 & 11.54 \\
\hline Garcinia nigrolineata & G. nig & 3.29 & 2.01 & 7.88 & 9.12 \\
\hline Garcinia speciosa & G. spe & - & 7.25 & 2.66 & 1.5 \\
\hline Heritiera javanica & H. jav & - & 2.33 & - & 0.46 \\
\hline
\end{tabular}




\begin{tabular}{|c|c|c|c|c|c|}
\hline \multirow{2}{*}{ Species } & \multicolumn{5}{|c|}{ IVI } \\
\hline & Sp. code & Type 1 & Type 2 & Type 3 & Type 4 \\
\hline Hopea pierrei & H. pie & 23.59 & 30.55 & 114.4 & 61.63 \\
\hline Horsfieldia irya & H. iry & 2.28 & - & - & 3.39 \\
\hline Iravingia malayana & I. mal & 5.17 & - & - & 2.13 \\
\hline Ixora cibdela & I. cib & 0.7 & 1.17 & - & - \\
\hline Knema linifolia & K. lin & 2.48 & - & - & - \\
\hline Litchi chinensis & L. chi & 1.47 & - & - & - \\
\hline Lithocarpus ceriferus & L. cer & 16.11 & 6.35 & 1.02 & 3.56 \\
\hline Lithocarpus sp. & L. $s p$ & 2.85 & - & - & - \\
\hline Lithocarpus sp. 2 & L. sp2 & 4.4 & - & - & - \\
\hline Litsea pierrei & L. pie & 12.14 & 2.92 & 1.83 & 6.96 \\
\hline Lophopetalum duperreanum & L. dup & - & - & 0.62 & - \\
\hline Madhuca grandiflora & M. gra & 10.75 & 10.94 & 8.22 & 8.74 \\
\hline Madhuca pierrei & M. pie & 21.47 & 7.04 & 6.93 & 11.21 \\
\hline Mangifera caloneura & M. cal & - & - & 1.3 & 2.02 \\
\hline Maytenus marcanii & M. mar & 0.7 & 1.12 & 0.64 & - \\
\hline Melanorrhoea usitata. & M. usi & - & - & 6.33 & 9.54 \\
\hline Memecylon garcinioides & M. gar & 5.26 & 12.46 & 12.61 & 15.76 \\
\hline Mesua ferrea & M. fer & 2.01 & 34.7 & 6.09 & 1.58 \\
\hline Ochna integerrima & O. int & 4.25 & - & - & - \\
\hline Oncosperma tigillaria & O. tig & - & - & - & 2.69 \\
\hline Paeinari anamense & P. ana & 1.5 & - & - & - \\
\hline Phyllanthus emblica & P. emb & - & - & 0.96 & - \\
\hline Scaphium macropodum & S. $m a c$ & 7.39 & 2.39 & 4.41 & 7.91 \\
\hline Semecarpus Sp. & S. $s p$ & 6.82 & 2.01 & 5.26 & - \\
\hline Shorea hypochra & S. hyp & 8.62 & 9.31 & 6.42 & 8.23 \\
\hline Sloanea sigum & S. sig & - & 4.67 & 2.78 & 2.67 \\
\hline Spondias bipinnata & S. bip & 2.22 & - & - & - \\
\hline Sterculia foetida $\mathrm{L}$. & S. foe & - & - & 1.22 & - \\
\hline Syzygium diospyrifolium & S. dio & 0.7 & - & - & - \\
\hline Tetrameles nudiflora & T. nud & 24.96 & - & 0.7 & 1.94 \\
\hline Vatica odorata & V. ode & - & 12.87 & 6.91 & 5.68 \\
\hline Walsura angulata & W. ang & 3.57 & - & 1.95 & 2.69 \\
\hline Xerospermum noronhianum & $X$. nor & 5.82 & 1.01 & 1.46 & - \\
\hline Unknow 1 & Uk1 & - & - & - & 0.47 \\
\hline Unknow 2 & Uk2 & 1.39 & - & - & - \\
\hline Unknow 3 & Uk3 & 1.2 & - & - & - \\
\hline Unknow 4 & Uk4 & 0.7 & - & - & - \\
\hline Unknow 5 & Uk5 & - & 2.32 & - & - \\
\hline Unknow 6 & Uk6 & 0.78 & - & 0.64 & - \\
\hline
\end{tabular}

Note: ${ }^{*}$ The gray shading for some IVI values indicate IVI values $\geq 15(5 \%)$ for each community. ter analysis on a small island tends to overlap (a result of the CCA ordination graph shown in Figure 3), it clearly showed a difference in the abundance of dominant species. Hopea pierrei Heim (Dipterocapus) was found in all the communities, including the Hopea pierrei Heim community, secondary succession community, Calophyllum thorelii Pierre community, and lowland multi-aged stands, but with different IVIs, which were $38.15 \%, 20.54 \%, 10.18 \%$, and $7.86 \%$, respectively. A similar pattern was obtained when a cluster analysis was performed on the literal evergreen forest of Samesan Island (Payomrat, 2011). Ordination diagram and species composition of five sub-community types showed an overlap of Memecylon plebejum, which is a dominant species between four communities, but different IVI ratios were observed. However, some studies of small islands have identified distinct vegetation communities using cluster analysis. Phra Thong Island has a large alluvial deposit sand plain with sinking seashore and productive mudbeaches on estuaries of many long rivers, which is different than the terrain of Chang Island. This island covers the Cajuput forest, Cajuput swamp, Peat swamp forest, Beach forest, grasslands, and mangroves (Pumijumnong, 2005). Cluster analysis of the sub-forest community (Thaisatuen, 2010) and Poaceae and Cyperaceae (Boutrat, 2009) on Phra Thong Island were successfully classified as communities with $60 \%$ - 95\% remaining information, which is similar to the present study, with the exception of the grassland type.

\section{Relationship between Communities and Topographic Factors}

Elevation and TWI were similarly important factors controlling the community distribution of Chang Island. The eigenvalues in an ordination analysis represent the relative contribution of each axis to the explanation of the total variation in the data. The CCA eigenvalues of the 3 two ordination axes were $0.303,0.253$, and 0.172 , respectively (Table 3 ). A Monte Carlo test confirmed the statistical significance of the axes $(P=0.05)$. The first three axes explained $12.5 \%$ of the variance in the species data. From the Table 4, the highest intraset correlations with axis 1 was TWI (0.819) and axis 2 was the elevation $(-0.858)$.

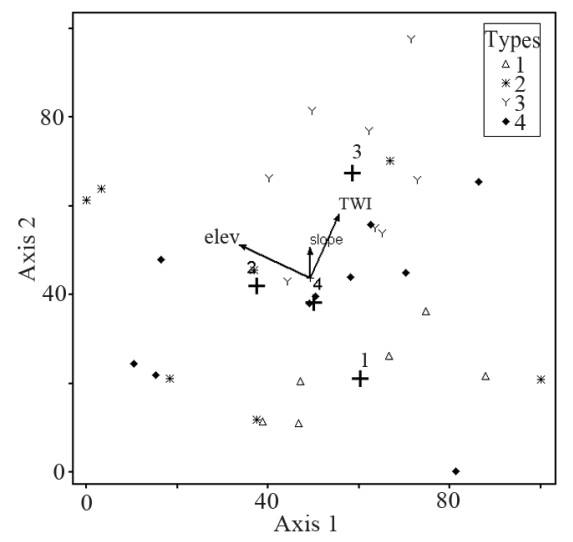

Figure 3.

CCA plot ordination with the community types derived from cluster analysis. Type $1=$ lowland multi-aged stands; Type 2 = Calophyllum thorelii Pierre community; Type $3=$ Hopea pierrei Heim community; and Type $4=$ secondary succession community. 
Table 3.

Summary statistics table for the CCA ordination.

\begin{tabular}{cccc}
\hline & Axis 1 & Axis 2 & Axis 3 \\
\hline CCA & & & \\
Eigenvalues & 0.303 & 0.253 & 0.172 \\
\% of variance explained & 5.2 & 4.3 & 2.9 \\
Cumulative \% explained & 5.2 & 9.6 & 12.5 \\
Pearson correlation & 0.981 & 0.88 & 0.894 \\
\hline
\end{tabular}

Table 4.

Canonical coefficients and intraset correlations of environmental variables with the first three axes of the CCA.

\begin{tabular}{ccccccc}
\hline & \multicolumn{3}{c}{ Canonical coefficients } & \multicolumn{2}{c}{ Canonical coefficients (intraset) } \\
\hline Variable & Axis 1 & Axis 2 & Axis 3 & Axis 1 & Axis 2 & Axis 3 \\
TWI & 0.299 & 0.609 & 0.311 & 0.35 & 0.819 & 0.456 \\
Elevation & -0.734 & 0.315 & -0.199 & -0.858 & 0.424 & -0.291 \\
Slope & 0.002 & 0.29 & -0.629 & 0.002 & 0.39 & -0.921 \\
\hline
\end{tabular}

Vectors representing environmental variables are shown in Figure 3. The length of the vector is proportional to its importance and the angle between two vectors reflects the degree of correlation between the variables. The angle between a vector and each axis is related to its correlation with the axis. Only variables with a correlation coefficient higher than 0.5 are represented in order to compare the classification between the cluster analysis result and CCA ordination. The derived community types are not clearly separated. Low-land multi-aged stands (Type 1) and Hopea pierrei Heim community (Type 3) grouped well on the upper right and lower right, respectively. The Calophyllum thorelii Pierre community (Type 2) and Secondary succession community (Type 4) have an overlapping distribution on the lower to mid-gradient.

TWI, which combines the local upslope contributing area and slope, is commonly used to quantify the control of hydrology, and therefore is used to define local topographic characteristics as a better representation than slope gradient alone. Many studies have showed a correlation between TWI, soil moisture, soil water level, ground water level, soil $\mathrm{pH}$, and vascular plant species richness (Sørensen, 2005; Zinko et al., 2005; Giesler et al., 1998). Relative wetness in TWI tends to increase the richness in species and diversity. A comparison of TWI of the communities, species richness, and species diversity in this study showed that relative TWI tended to have a positive correlation with species richness (number of species)in three communities on the sloping area (Calophyllum thorelii Pierre community Type 2, Hopeapierrei Heim community Type 3, and secondary succession community Type 4). However, a negative correlation with species was observed. The community with the highest diversity and species richness, lowland multiaged stands (Type 1), did not depend on the TWI value. This community is located on the flatland near the foot hill where the deepest soil affected the distribution of old trees with multilayered strata. Soil moisture and humidity in the understory are high and much more stable compared to the canopy. TWI had a negative correlation with species diversity because of the success of Hopea pierrei Heim in the wetness area succession. As shown in Figure 4, Hopeapierrei Heim was highly responsive to TWI, so much so that the others species had a reduced priority and the Shannon-Wiener index was decreased (Tables 1 and 2).

We selected key species by choosing species with an IVI value $\geq 15$ or $5 \%$ from each community. Four species from the lowland multi-aged stands (Type 1) were Tetrameles nudiflora R. Br. (TETRAMELACEAE), Hopea pierrei Heim (DIPTEROCARPACEAE) Madhuca pierrei Lam (SAPOTACEAE), Lithocarpus ceriferus A. Camus (FAGACEAE), and Ficus callosa Willd (MORACEAE). Four species from the Calophyllum thorelii Pierre community (Type 2) were Calophyllum thorelii Pierre (GUTTIFERAE), Mesua ferrea Linn. (GUTTIFERAE), Hopea pierrei Heim (DIPTEROCARPACEAE), and Cleistocalyx operculatus Merr. and Perry (MYRTACEAE). Two species from the Hopea pierrei Heim community (Type 3) were Hopea pierrei Heim (DIPTEROCARPACEAE) and Cleistocalyx operculatus Merr. and Perry (MYRTACEAE). Four species from the secondary succession community (Type 4) were Hopea pierrei Heim (DIPTEROCARPACEAE), Calophyllum thorelii Pierre (GUTTIFERAE), Cleistocalyx operculatus Merr. and Perry (MYRTACEAE), and Memecylon garcinioides Bl. (MEMECYLACEAE). The IVI values of each species are shown in Table 2. A fit response curve created a turnover point of communities responding with TWI. Low land multi-aged stands (Type 1) and some species from the Calophyllum thorelii Pierre community (Type 2 ) occupied relative dry in TWI and turnover to Dipterocapus community (Type 3,4) and Calophyllum thorelii Pierre community (Type 2) when TWI higher than 2, as defined by a moderate level of Hopea pierrei Heim abundance (key species of Type 3,4) and Cleistocalyxo perculatus Merr. and Perry (key species of Type 2). However, the assumption of a high value of TWI occurred with the appearance of a creek based on field survey (TWI $>5$ ), even if some of species, such as Hopea pierrei Heim, Ficus callosa Willd, and Tetrameles nudiflora R. Br. occupied this area.

Dipterocapace (Hopea pierrei Heim) were successfully distributed along all environmental gradients of Chang Island and were found in all strata. A characteristic feature of these plants is the amount of sunlight that can be tolerated during development. An emergent dipterocarp has a crown that receives full sunlight during the entire day, whereas as a seedling, it not only requires tolerant shade, but it will die when subjected to full sunlight during the entire day (Göltenboth, 2007). Thus, clear cutting of the forest will be a serious problem for dipterocarp, as seedlings will have less of a chance to survive. Buttress roots

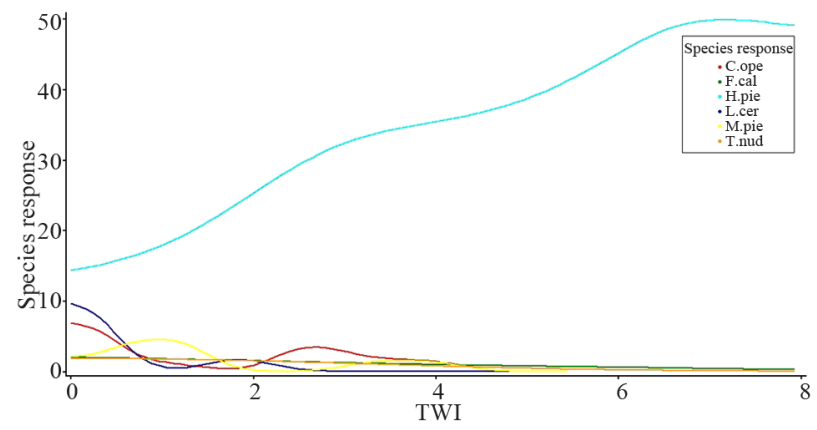

Figure 4.

Fit response curves between key species and TWI (the species codesare show in Table 2). 
are another characteristic feature of dipterocarp (common name of Hopea pierrei Heim is TaKhianRak; "Rak" means root in Thai). It occurs when trees with a shallow root system prevail in areas where nutrient concentrations are largest near the soil surface or stand against a steep slope. Why these structure are formed is still not fully understood, as research has shown that buttresses do not increase the trees' resistance to mechanical stress, such as trunk snapping, or alleviate the pulling strain on the roots (Richard, 1996).

Elevation was positively correlated with tree density $(\mathrm{r}=$ 0.979). The Calophyllum thorelii Pierre community (Type 2), which was distributed along the high land until the peak, had the highest tree density $\left(2225 \mathrm{tree} \cdot \mathrm{ha}^{-1}\right)$, whereas the tree density of the Hopea pierrei Heim community (Type 3), secondary succession community (Type 4), and low land multi-aged stands (Type 1) were 1807, 1782, and 1287 tree ha ${ }^{-1}$, respectively. This relation pattern is seen in the tropical rainforest of Phukhet Island as well (Kiratiprayoon, 1986). Normally, high density leads to a high percentage of basal area, but the basal area of Chang Island was not increased. TWI showed a positive correlation with the basal area in this study $(\mathrm{r}=0.928)$. The average TWI of Hopea pierrei Heim community (Type 3), secondary succession community (Type 4), Calophyllum thorelii Pierre community (Type 2), and low land multi-aged stands (Type 1) was $4.13 \pm 2.36,1.70 \pm 1.95,1.29 \pm 1.16$, and $0.5 \pm$ 0.55 , respectively, while the percentage of basal area was $0.5886 \%, 0.4056 \%, 0.3396 \%$, and $0.3845 \%$, respectively. Many studies have shown the same results as our study, where moisture is a factor that can potentially control the above ground biomass in 6 forest types of Thailand: tropical evergreen rain forest, seasonal rain forest, lower mountain coniferous forest, upper mountain rain forest, mixed deciduous forest, and deciduous dipterocarp forest (Working group I: Scientific Basis of Climate Change, 2011; Rueangruea, 2009; Sunthisuk, 2006; Kiratiprayoon, 1986). Species response curve with regard to elevation showed six key species responding in three patterns (Figure 5). The Hopea pierrei Heim curve primarily showed a bell-shape curve (abundant at mid-elevation), which intersected the Calophyllum thorelii Pierre curve at an elevation at $550 \mathrm{~m}$ asl. It can be concluded that the Dipterocarpus (Hopea pierrei Heim) community tends to turnover to the Calophyllum thorelii Pierre community at elevations greater than $550 \mathrm{~m}$ asl, and turnover to the secondary succession community (Type 4) at low elevation with an increase of Memecylon garcinioides Bl., which is the other key species of this community. The response curve of Madhuca pierrei Lam and Tetrameles nudiflora $\mathrm{R}$. Br., which are key species of lowland multi-aged stands (Type1), showed a negative correlation with elevation. A positive correlation of the Mesua ferrea Linn curve (key species of Calophyllum thorelii Pierre community, Type 2) intersected the Madhuca pierrei Lam curve at an elevation of $250 \mathrm{~m}$ asl. Moreover, the decrease of Hopea pierrei Heim at a low elevation suggests that the limit of distribution of lowland multi-aged stands (Type1) is $250 \mathrm{~m}$ asl. Lithocarpus ceriferus A. Camus, Cleistocalyx operculatus Merr. and Perry, and Ficus callosa Willd were excluded because these species did not respond to a change in elevation (the curves ran parallel with the $\mathrm{x}$-axis).

\section{Area of Community}

Based on the fit respond curve for elevation and TWI, we conclude that the environmental conditions of each community are as follows: Lowland multi-aged stands (Type 1): Elevation $<250 \mathrm{~m}$ asl and TWI $<2$, Calophyllum thorelii Pierre community (Type 2): Elevation $>250 \mathrm{~m}$ asl and TWI $<5$, Hopea pierrei Heim community (Type 3): $250<$ Elevation $<550 \mathrm{~m}$ asl and $2<$ TWI $<5$, Secondary succession community (Type 4): Elevation $<550$ asl and $2<$ TWI $<5$ and Creek representation: All elevation gradient and TWI $>5$.

From the Figure 6, the total forest area was 17428.45 ha, which was comprised of low land multi-aged stands Type 1 (4807.99 ha or $27.59 \%$ ), Calophyllum thorelii Pierre community Type 2 (5300.04 ha or $30.41 \%$ ), Hopea pierrei Heim community Type 3 (2358.54 ha or 13.53\%), secondary succession community Type 4 (3731.24 ha or $21.41 \%)$, and creek area $(1230.65$ ha or $7.06 \%)$. Some areas of the secondary succession community were complicated. These areas were composed of

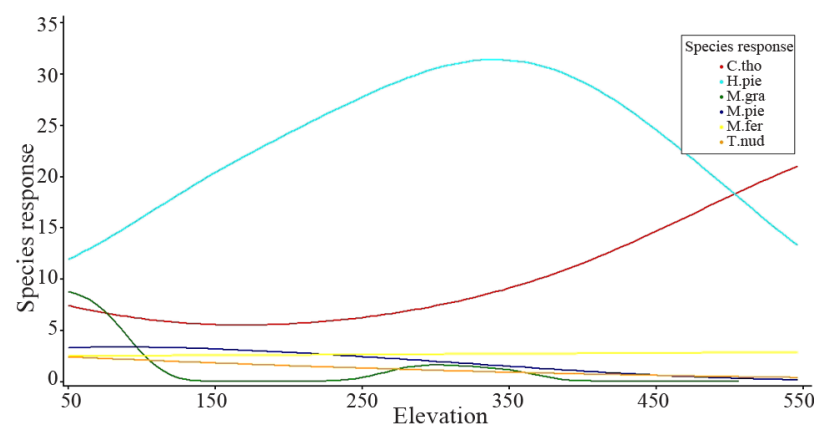

Figure 5.

Fit response curves between key species and elevation (the species codes are shown in Table 2).

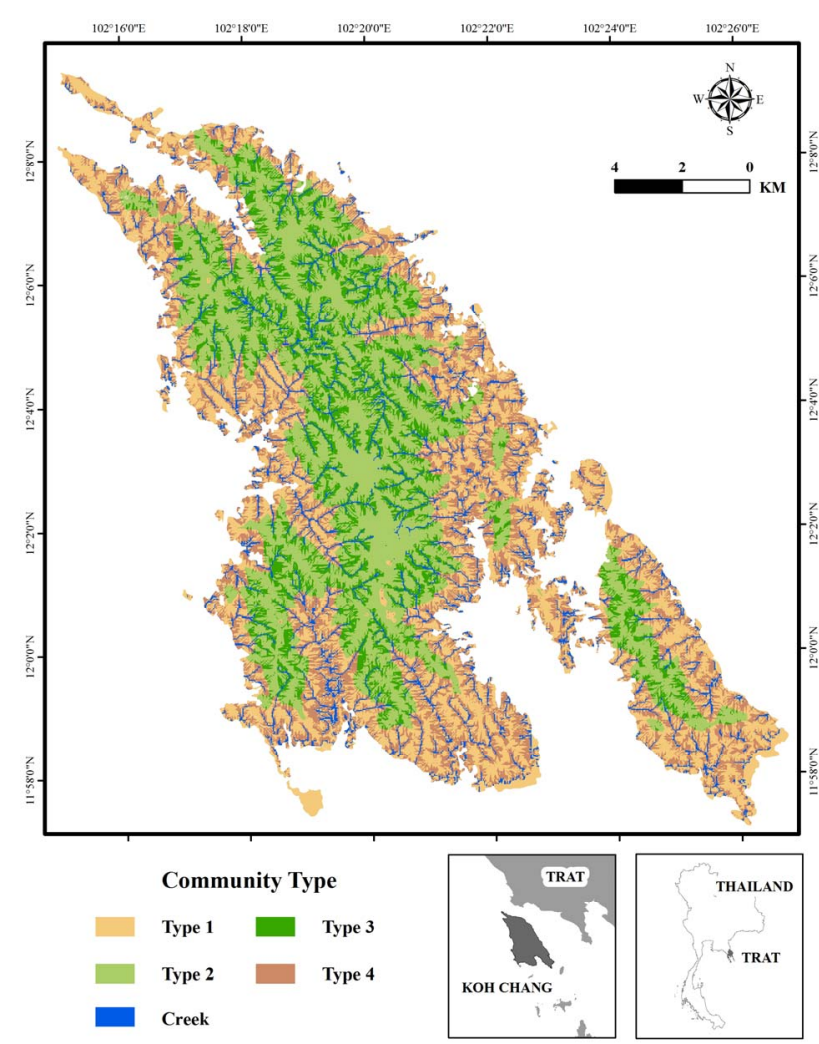

Figure 6.

Area of four community types (Type 1-4) and creek. 
two probable communities: the natural Dipterocarpus community and secondary succession community, because one of the factors controlling the secondary succession community was human disturbance. Therefore, it was not included in this study.

\section{Conclusion}

Chang Island has a particularly high evenness and richness of species. We investigated an area of 2.48 ha and recorde total of 78 species from a total of 32 families. Two-way cluster analysis classified the tropical rain forest into four sub-communities: lowland multi-aged stands (Type 1), Calophyllum thorelii Pierre community (Type 2), Hopea pierrei Heim community (Type 3), and secondary succession community (Type 4). Elevation and the topographic wetness index (TWI) affected the distribution of each community. Lowland multi-age stands, which had the highest diversity and richness, correlated with low elevation and relatively low TWI or dry conditions. The Calophyllum thorelii Pierre community had the highest tree density and correlated with high elevation and relative moderate to dry TWI conditions. The Hopea pierrei Heim community had the highest percentage of basal area and the lowest diversity, and was extensively covered by the Hopea pierrei Heim species. It correlated with a mid-elevation near creeks and had relatively wet TWI conditions. Finally, the secondary succession community (Type 4) was related to mid to low elevation and relatively moderate to wet TWI conditions.

\section{REFERENCES}

Bird, M. I., Taylor, D., \& Hunt, C. (2005). Palaeoenvironments of insular southeast Asia during the last glacial period: A savanna corridor in Sundaland? Quaternary Science Reviews, 24, 2228-2242. doi:10.1016/j.quascirev.2005.04.004

Boutrat, W. (2009). Relationship between soil properties with Poaceae and Cyperaceae on the grassland at Phra Thong island, Kuraburi district, Phangnga province. Master Thesis, Nakron Pratom: Mahidol University

Chamchumroon, V., \& Puff, C. (2003) The Rubiaceae of Ko Chang, southeastern Thailand. Thai Forest Bulletin (Botany), 31, 13-26.

Curtis, J. T. (1959). The vegetation of Wisconsin. Madison: University of Wisconsin Press.

Environmental Research Institute (2007). Study area and the index of environmental quality to sustainable tourism and the island group project (phase 2). Bangkok: Chulalongkorn University.

Esselstyn, J. A. \& Brown, R. M. (2009). The role of repeated sea-level fluctuations in the generation of shrew (Soricidae: Crocidura) diversity in the Philippine Archipelago. Molecular Phylogenetics and Evolution, 53, 171-181 doi:10.1016/j.ympev.2009.05.034

Finch, H. (2005). Comparison of distance measures in cluster analysis with dichotomous data. Journal of Data Science, 3, 85-100.

Giesler, R., Högberg, M., \& Högberg, P. (1998). Soil chemistry and plant in Fennoscandian boreal forest as exemplified by a local gradient. Ecology, 79, 119-137. doi:10.1890/0012-9658(1998)079[0119:SCAPIF]2.0.CO;2
Göltenboth, F., Langenberger, G., \& Widmann, P. (2007). Tropical loland evergreen rainforest. Ecology of Insular Southeast Asia: The Indonesian Archipelago, 297-384.

Hill, D., Fasham, M., Tucker, G., Shewry, M., \& Shaw, P. (2007). Handbook of biodiversity methods. Cambridge: Cambridge University Press.

Kiratiprayoon, S. (1986) Comparative study on the structure of the rattan bearing tropical rain forests. Master Thesis, Bangkok: Kasetsart University

McCune, B., \& Grace, J. B. (2002). Analysis of ecological communities. Glenden Beach: MJM Software Design.

Office of Science for Land Development (2005). Manual analysis of soil, water, fertilizers, soil and plant analysis for certification (2nd ed.). Bangkok: Land Development Department.

Payomrat, P. (2011). Effects of ecological factors on vegetation and carbon stocks at Samesan island, Chonburi, Thailand. Master Thesis, Nakron Pratom: Mahidol University

Pumijumnong, N. (2005). Effects of the tsunami on the Pra Thong island ecosystem. Nakron Pratom: Mahidol University.

Richards, P. W. (1996). The tropical rainforest: An ecological study. Cambridge: Cambridge University Press.

Royal Forest Department (1997). Master plan report Koh Chang marine national park, Trad province. The land and forest resources. Conservation of natural resources.

Royal Forest Department. (2005). Master plan report Ton Nga Chang wildlife sanctuary, Songkhla province.

Rueangrues, S. (2009). Structure of Montane forests in Thailand. Master Thesis, Bangkok: Kasetsart University

Santhisuk, T. (2006). Forest of Thailand. Bangkok: Department of National Parks, Wildlife and Plant Conservation.

Schmidt, J. (1900). Flora of Koh Chang: Contributions to the knowledge of the vegetation in the Gulf of Siam. Copenhagen: B. Luno. doi:10.5962/bhl.title. 55188

Sørensen, R., Zinko, U., \& Seibert, J. (2005). On the calculation of the topographic wetness index: Evaluation of different methods based on field observation. hydrology and earth system sciences discussions, 1807-1834.

Tansuwan, V., \& Kitisarom, N. (2007). Study report of geology, Chang island, Trat Province. Bureau of Geology, Department of Mineral Resources.

ter Braak, C. J. F., \& Verdonschot, P. F. M. (1995). Canonical correspondence analysis and related multivariate methods in aquatic ecology. Aquatic Science, 57, 255-289. doi:10.1007/BF00877430

Thai Meteorological Department (2010). Data of climate between the years 1990-2009 at Khlong Yai station, Trat province.

Thaisatuen, T. (2010). Multivariate analysis of relationship between plant communities and soil properties on Phra Thong island, Kuraburi district, Phangnga province. Master Thesis, Nakron Pratom: Mahidol University.

Tougard, C. (2001). Biogeography and migration routes of large mammal faunas in South-East Asia during the late middle pleistocene: Focus on the fossil and extant faunas from Thailand. Palaeo, 168, 337-358.

Working Group I: Scientific Basis of Climate Change (2011). Thailand's first assessment report on climate change 2011. Bangkok: The Thailand Research Fund.

Zinko, U., Seibert, J., Dynesius, M., \& Nilsson, C. (2005) Plant species numbers predicted by a topography based groundwater-flow index. Ecosystem, 8, 430-441. doi:10.1007/s10021-003-0125-0 